\title{
炭素熱還元法によるアルミニウム-鉄系合金の調製
}

\author{
亀山哲也・本江秋弘・藤井欽二郎 \\ (化学技術研究所)
}

\section{Carbothermical Preparation of Aluminum-Iron Alloys}

Tetsuya KAMEYAMA, Akihiro MOTOE and Kinjiro FUJII

$\left(\begin{array}{lr}\text { National Chemical Laboratory for Industry } \\ \text { Yatabe-cho, Tsukuba-gun, Ibaraki } 305\end{array}\right)$

\begin{abstract}
A high yield of aluminum alloys was difficult to achieve with a blast furnace, because both heating samples and reducing samples were done in the same chamber. In this report, we achieved a high yield of Al-Fe alloys, 70 wt\%, by carbothermic reduction of $\mathrm{Al}_{2} \mathrm{O}_{3}-\mathrm{Fe}_{2} \mathrm{O}_{3}-\mathrm{C}$ samples using a new indirect heating method. The method for preparing the sample to be reduced was based on the reduction mechanism of alumina. The sample was prepared by mixing graphite powders (0.3-0.5 $\mathrm{mm})$ coated with fine $\alpha-\mathrm{Fe}_{2} \mathrm{O}_{3}$ powders $(1 \mu \mathrm{m})$ and $\alpha-\mathrm{Al}_{2} \mathrm{O}_{3}$ powders $(20-80 \mu \mathrm{m})$ and subsequent compaction.
\end{abstract}

[Received February 7, 1986]

Key-words : $\mathrm{Al}_{2} \mathrm{O}_{3}-\mathrm{Fe}_{2} \mathrm{O}_{3}-\mathrm{C}$, Carbothermic reduction, Al-Fe alloy

\section{1. 緒 言}

アルミニウム製錬は，現在，ホール・エール電解法に より行われているが，その製錬コストの大略 $50 \%$ が電 力料金で占められるため, 電力料金が他国に比べて著し く高い我が国では極めて経済性の悪いものとなってい る.これを解決するためにアルミニウム製錬を溶鉱炉法 により行う方法も提案・検討されてきている1) 3). しか しながら，溶鉱炉法では原料の加熱・還元とその加熱還 元に必要な石炭やコークスの燃焼が同一炬内で行われる ため, 操作上種々の困難が生じる．例えば炉内において は原料の還元に必要な $2000^{\circ} \mathrm{C}$ 以上の高温を発生させる ために，多量のコークスや石炭の燃焼が必要とされ，そ の結果多量の $\mathrm{CO}$ ガスが発生する。 そして, 炉内にお いて発生した $\mathrm{Al}_{2} \mathrm{O}, \mathrm{SiO}, \mathrm{SiO}_{2}$ などの蒸発種はこの多 量の $\mathrm{CO}$ ガスによって上層に運ばれ，ここで疑縮して ブリッジングやフラッディング現象を生じやすいのみな らず，多量の CO ガスによって炉外へ運ばれるため, アルミニウム分の損失が極めて多い. 更に，いったん生 成した粗合金も，燃焼域近傍の酸素分圧が高いために再 酸化を受け，アルミニウム分の収量は低下してしまう.

このように, 同一炉内において原料の加熱還元と, そ の加熱還元に必要な石炭やコークスの燃焼とを同時にか つ円滑に行うことは極めて困難であることから, 高温で の間接加熱方法が別途研究されてきた。しかしながら, 従来の間接加熱炉の場合，燃焼炉と加熱炬との間の熱伝 達を行わせる隔壁は，耐熱鋼や炭化ケイ素等の材料から 構成されるため ${ }^{4)}$, その耐熱温度は最高 $1300^{\circ} \mathrm{C}$ 程度で ありボーキサイトやアルミナの加熱還元に必要な $2000^{\circ} \mathrm{C}$ 以上の高温に耐えるものではなく，また，熱伝 導性の点でも十分でないため効率的な熱伝達を行うこと が困難である。

この点を克服するため, 別途研究中の高温間接加熱炉 では，燃焼室で発生させた高温の熱 (約 $2000^{\circ} \mathrm{C}$ ) を金 属の銅の溶融体と, これに接触する黒鉛の隔壁を介して 加熱室へ伝達させる方式をとった5).この新高温炉の利 用を想定し，炭素還元によるアルミナからの $\mathrm{Al}-\mathrm{Fe}$ 合 金の製造につき，特に品質と収率の改善を意図して実験 を行ったので報告する。

\section{2. 実 験}

\section{1 試料の調製と加熱方法}

アルミナのみの炭素熱還元によるアルミニウムの製造 は, アルミニウムの蒸発のために不可能であり ${ }^{6)}$, シリ カあるいは酸化鉄を添加してアルミニウムを合金化さ せ，アルミニウム活量を下げてアルミニウムの蒸発を抑 えることが必要である．活量を下げる効果はケイ素より 鉄の方が大きいこと7), また, 合金の生成温度が下げら れ融液の粘度が下がって流れやすくなるほど, 炬操作が 容易になることから ${ }^{8)}$, ここでは酸化鉄を添加した. 更 に, アルミニウム合金生成機構として, 溶融鉄に溶解し た炭素がアルミナの還元に寄与している可能性が大きい と言われていることから9，以下のようにあらかじめ酸 化鉄を被覆した黒鉛粒子とアルミナ粉末とからペレット を圧縮成形して試料とした. なお, アルミナ含有原料に 対する炭素材の添加量は, $\mathrm{Al}_{2} \mathrm{O}_{3}+3 \mathrm{C} \rightarrow 2 \mathrm{Al}+3 \mathrm{CO}$ で 表される化学量論以上必要である. 
試料としては，0.3〜0.5 mm 径の黒鉛粒子 $(99.9 \%)$ の表面に, 均一に約 $1 \mu \mathrm{m}$ の微粒子の $\alpha-\mathrm{Fe}_{2} \mathrm{O}_{3} \quad(99.9 \%)$ を少量の糊料を用いてコーティングし，次にこの被覆粒 子と所定量の $20 \sim 80 \mu \mathrm{m}$ の微粒子の $\alpha-\mathrm{Al}_{2} \mathrm{O}_{3}$ (99.9\%) を混合したものを加圧成形し， $10 \mathrm{~mm}$ 径，高さ $15 \mathrm{~mm}$ のペレットを用いた。重量比は $\alpha-\mathrm{Al}_{2} \mathrm{O}_{3}: \alpha-\mathrm{Fe}_{2} \mathrm{O}_{3}: \mathrm{C}=$ $60 ： 15 ： 25$ である.

加熱用燃焼炬としては横型ガス炉を用いた ${ }^{10)}$. 図1の ように都市ガス燃焼室内（A）に黒鉛製のるつぼ（3） を置き，その中に加熱室 (B) を設けてここに上述のぺ レット試料を入れ，アルミニウムー鉄系合金の調製を試 みた。その際，（2）には，銅の融体層を形成させるた めに銅の粉末（0.1〜0.2 mm 径）を充てんしておいた. この融体層は，これに接する隔壁としての黒鉛板（4) が燃焼室に存在する酸素と反応して酸化されるのを, 更 には酸素が加熱室 (B) に混入するのを防ぐことを目的 とする.

燃焼室（A）で発生させた熱は金属銅の溶融体層を通 り，黒鉛板体を通って黒体輻射により加熱室（B）内に 伝達され，試料ペレットの温度を上昇させ，還元反応を 進ませる，この場合，加熱室 (B) 内は黒鉛表面がその まま露出しているため, 加熱室内はあらかじめアルゴン ガスで置換し，酸素の存在しない状態にしておいた。な お，黒鉛るつぼの外径は $40 \mathrm{~mm}$, 高さは $45 \mathrm{~mm}$, 加熱 室の内径は $20 \mathrm{~mm}$, 高さは $15 \mathrm{~mm}$ である.

加熱室内の温度は光高温計を用いて測定した．輝度温 度と加熱室内の温度との関係は，加熱室内においたパラ ジウム $\left(\mathrm{mp}: 1554^{\circ} \mathrm{C}\right)$ ，白金 $\left(\mathrm{mp} 1772^{\circ} \mathrm{C}\right)$, 及びロジ ウム $\left(\mathrm{mp}: 1963^{\circ} \mathrm{C}\right)$ のそれぞれの融点から求めた.

\section{2 分析方法}

還元生成物は，主に粉末 X 線回折法により同定した. 生成した $\mathrm{Al}-\mathrm{Fe}$ 合金の重量並びにそれらの組成比は, 以下に示す生成合金の塩酸溶解によるガス発生法並びに

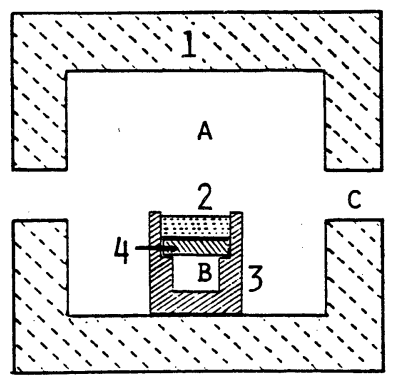

Fig. 1. Schematic diagram of a furnace.

A : Combustion chamber, B : Heating chamber, C: Gas burner,

1 : Aluminous refractory insulator,

2 : Molten copper layer,

3: Graphite crucible,

4: Graphite plate
水酸化アンモニウムによる沈殿法からそれぞれ求めた. 最初に試料約 $0.5 \mathrm{~g}$ を塩酸 $(1: 1) 50 \mathrm{cc}$ に溶解し，そ の際発生した水素ガス及びメタンガスの各容量をガスク ロマトグラフにより求めた。水素ガス量は生成した金属 アルミニウムと金属鉄の合計量に，メタンガス量は $\mathrm{Al}_{4} \mathrm{C}_{3}$ の量にそれぞれ対応している．金属アルミニウム に対する金属鉄の量比は，金属を溶解した上述の塩酸約 $25 \mathrm{cc}$ に水酸化アンモニウム溶液を添加して得られた沈 殿物の， $\alpha-\mathrm{Al}_{2} \mathrm{O}_{3}$ に対する $\alpha-\mathrm{Fe}_{2} \mathrm{O}_{3}$ の量比から換算して 決めた.

\section{3. 結果と考察}

炉温 $2150^{\circ} \mathrm{C}$ で 30 分保持し，還元を試みた. その結果， 試料はねずみ色の金属状の光沢を示し，均一なスポンジ 状になっていた，形状は保っていたが，もろかった。こ れを周辺部と中心部に分け，生成相を同定した（表 1 ). 両部で回折パターンに有為の差が認められなかったこ と，アルミナや酸化鉄が検出されなかったことから，還 元反応は均一に, かつ,ほぼ完全に進んでいたといえる. 主成分は, $\mathrm{Fe}_{2} \mathrm{Al}_{5}, \mathrm{FeAl}_{3}, \mathrm{Fe}_{4} \mathrm{Al}_{13}$ の混合物からなる 合金相であり，未同定相，微量の $\mathrm{Al}_{2} \mathrm{OC}, \mathrm{Al}_{4} \mathrm{C}_{3}$ も存在 していた. Al, $\alpha-\mathrm{Fe}$ のピークは認められなかった。

黒鉛るつぼの外側の表面はザラザラしていたが，金属 銅の溶融体で覆われた内側の黒鉛の表面は顕著な変化が みられなかった. また金属銅の表面も金属の光沢を示し ていた，黒鉛るつぼの外側がザラザラしていたのは然焼 室に残存する酸素により酸化を受けたためであろう。一 方，加熱室内の黒鉛の表面が変化していなかったのは， 金属銅により燃焼室からの酸素の混入が防がれていたか らであろう．加熱室内は最初から存在していたアルゴン ガスと, 試料の炭素熱還元により発生した CO ガスの みで占められていたと考えられる，また，燃焼室内にお ける銅の酸化反応に関しては $4 \mathrm{Cu}(\mathrm{S})+\mathrm{O}_{2}=2 \mathrm{Cu}_{2} \mathrm{O}$ における酸素の平衡分圧が $2000^{\circ} \mathrm{C}$ で約 1 気圧，高温ほ ど酸化されにくいことから，実験終了後も金属銅の光沢

Table 1. Analysis of product.

\begin{tabular}{|c|c|c|c|c|}
\hline \multirow{2}{*}{$X$-ray analysis } & \multicolumn{3}{|c|}{ wet analysis } & \\
\hline & $\begin{array}{l}\text { product } \\
\text { (gr) }\end{array}$ & $\begin{array}{l}\text { dissolved } \\
\text { (gr) }\end{array}$ & $\begin{array}{l}\text { evolved } \\
\mathrm{H}_{2} \\
\text { (cc) }\end{array}$ & $\begin{array}{l}\frac{\text { gas }}{\mathrm{CH}_{4}} \\
\text { (cc) }\end{array}$ \\
\hline $\begin{array}{l}\mathrm{Fe}_{2} \mathrm{AT}{ }_{5}+\mathrm{Fe} \mathrm{Al}_{3}+\mathrm{Fe} e_{4} \mathrm{Al} 13, \\
\mathrm{Al}_{2} \mathrm{OC}, \mathrm{Al}_{4} \mathrm{C}_{3} \text {, unknown, }\end{array}$ & 0.337 & 0.248 & 40.3 & 1.86 \\
\hline
\end{tabular}

Table 2. Comparison of metal yields.

\begin{tabular}{lcc}
\hline & blast furnace ${ }^{3)}$ & present \\
\hline $\begin{array}{c}\text { content of A1-Fe } \\
\text { (wt\%) }\end{array}$ & 20 & 70 \\
$\begin{array}{c}\text { content of Al } \\
\text { (wt\%) }\end{array}$ & 30 & 55 \\
\hline
\end{tabular}


を示していたのであろう．以上より金属銅は黒鉛板の酸 化損耗を防ぎ，加熱室内に酸素が混入するのを防ぐシー ル材としての役割を果たしていたと考えられる.

塩酸溶解法による結果も表 1 に示す. アルミニウム鉄合金量は $70 \%$ となり, 極めて収率よく合金が生成し ていた.この合金中のアルミニウムと鉄の量比は, 水酸 化アンモニウム溶液により得られた沈殿物を $1200^{\circ} \mathrm{C} て ゙$ 8 時間熱処理して得られた, $\alpha-\mathrm{Al}_{2} \mathrm{O}_{3}$ 亡 $\alpha-\mathrm{Fe}_{2} \mathrm{O}_{3}$ の量比 から求めた。お互いに固溶している量を考慮して求めた モル比, $\alpha-\mathrm{Al}_{2} \mathrm{O}_{3}: \alpha-\mathrm{Fe}_{2} \mathrm{O}_{3}=0.723: 0.277$ から換算す ると, FeAl2.61 になる. したがって, 合金相としてはX 線の回折図形のパターン及び格子定数も考慮して, $\mathrm{Fe}_{2} \mathrm{Al}_{5}$ が主な相であるといえる.

この結果を溶鉱炉方式で得られる合金の重量及び組成 比と比較して表 2 に示した．溶鉱炉方式 ${ }^{3)} に$ 比べて合金 量, 並びにアルミニウムの含量はかなり多い. 酸化鉄被 覆の炭素粒子を原料として, $\mathrm{Fe}-\mathrm{C}$ 系融液の利用によっ て間接加熱的に $\mathrm{Al}_{2} \mathrm{O}_{3}$ を還元することは有効であるとの
知見を得た. 今後, 改良によって実用的にも優れた方法 になる可能性を有しているといえる.

\section{文 献}

1) U.S. Patent, 4, 053, 303 (1977).

2) C. N. Cochran, Aluminium, 56, 233 (1980).

3) M. Dokiya, M. Fujishige, T. Kameyama, H. Yokokawa, S. Ujiie, K. Fukuda and A. Motoe, Light Metals, 1983, 651-70 (1983).

4) L. M. Pidgeon and W. A. Alexander, Trans. AIME., 159, 315 (1944).

5）亀山哲也, 長田 清, 本江秋弘, 横川晴美, 藤重昌生, 氏家誠一，藤井欽二郎，特願昭 57-46875,

6) M. M. Striplin, Chemical Engineering Progress, 43, 569 (1947).

7）三谷裕康, 永井 宏, 軽金属, 21, 789-95 (1971).

8）藤重昌生, 横川晴美, 亀山哲也, 氏家誠一, 本江秋弘, 福田健三, 土器屋正之, 日本金属学会誌, 47, 1047-54 (1983).

9）菊池武昭, 落合貞行, 黒沢利夫, 柳橋哲夫, 日本金属学 会誌, 34, 643-49 (1970).

10）長田 清, 本江秋弘, 藤井欽二郎, 窯協, 89, 270-75 (1981). 